\title{
A CHEGADA DO “OUTSIDER” AO RURAL-PARAÍSO: NOVOS ATORES E RELAÇÕES SOCIAIS E ECONÔMICAS NO CONTEXTO TURÍSTICO DA SERRA DE IBITIPOCA (MG)
}

\author{
LA LLEGADA DEL “OUTSIDER” EN EL RURAL-PARAÍSO: NUEVOS \\ ACTORES Y RELACIONES SOCIALES Y ECONÓMICAS EN EL CONTEXTO \\ TURÍSTICO DE LA SERRA DE IBITIPOCA - MG, BRASIL
}

\section{THE “OUTSIDER'S" ARRIVAL AT THE RURAL-PARADISE: NEW ACTORS AND SOCIAL AND ECONOMIC RELATIONS IN SERRA DE IBITIPOCA'S TOURIST SPACE -STATE OF MINAS GERAIS, BRAZIL.}

\author{
Bruno Pereira Bedim ${ }^{1}$ \\ Instituto de Geociências - Universidade Federal de Minas Gerais \\ brunobedim@yahoo.com.br \\ Maria Aparecida dos Santos Tubaldini ${ }^{2}$ \\ Instituto de Geociências - Universidade Federal de Minas Gerais \\ tubaldini1@uol.com.br
}

\begin{abstract}
Resumo
O artigo discute os processos derivados da apropriação da Serra de Ibitipoca por demandas urbanas, via turismo - enfocando o movimento processual de transformação de espaços até então caracterizados por atividades agrícolas de subsistência e peculiares formas de organização social. São analisadas as tensões desencadeadas pela chegada de novos atores sociais ao lugar, engendrando, assim, uma série de conflitos entre os recémchegados "forasteiros" e a população rural já estabelecida na região - os chamados "nativos". Têm-se no modelo teórico de Norbert Elias - o modelo das figurações sociais - como paradigma a nortear o estudo. Por conseguinte, demonstra-se como ambos os grupos disputam para si as posições de poder mais elevado, delineando estratégias de distinção social e disputas que envolvem tais relações. As mudanças observadas refletem o "rural" de Ibitipoca como espaço de (des)encontro entre temporalidades distintas, onde variados atores projetam diferentes representações, interesses e valores.
\end{abstract}

Palavras-chave: Turismo; Espaço rural; Mudança Social; Cultura local; Ibitipoca.

\footnotetext{
1 Autor. Mestre e Doutorando em Geografia (IGC-UFMG); Especialista em Ecoturismo e Planejamento (UFLA); Bacharel em Turismo (UFOP). O artigo condensa alguma das discussões que permeiam a dissertação desenvolvida pelo autor no Programa de Pós-Graduação em Geografia do IGCUFMG. Área de Concentração: Organização, Gestão e Produção do Espaço.

Orientadora e co-autora. Professora Adjunto IV do Departamento de Geografia - IGC/UFMG. Pós-Doutora em Desenvolvimento Rural pela Universidade Nova de Lisboa; Doutora em Geografia (UNESP).
} 


\title{
Resumen
}

El artículo investiga los procesos derivados de la apropiación de la Serra de Ibitipoca por necesidades urbanas, via turismo - destacando el movimiento procesual de transformación de espacios, hasta entonces caracterizados por actividades agrícolas de subsistencia y distintas formas de organización social. Son analisadas las tensiones desencadenadas por la llegada de nuevos actores sociales al sitio, engendrando, así, una série de conflitos entre los recién-llegados "forasteros" y la población rural que hace decadas estava establecida en la región - los llamados "nativos". El modelo teórico de Norbert Elias - modelo de las figuraciones sociales - se posiciona como paradigma a nortear el estudio. Por consecuencia, se demonstra como ambos los grupos disputan para si mismo las posiciones de poder mas elevado, delineando estrategias de distinción social y contiendas que arrollan dichas relacciones. Los cambios observados reflejan el "rural" de Ibitipoca como espacio de (des)encuentro de temporalidades distintas, donde varios actores proyectan diferentes representaciones, intereses y valores.

Palavras-Ilave: Turismo, Espacio rural, Cambio Social, Cultura Local, Ibitipoca.

\begin{abstract}
This article discusses the processes occurred from the appropriation of Serra do Ibitipoca by urban demands, via tourism - focusing on the transformation of the spaces which were until then characterized by traditional agricultural activities and peculiar forms of social organization. It analyzes the tensions brought up by the arrival of the new social actors to the area, which caused a series of conflicts between the new come outsiders and the peasants - who has been established in the region for decades. Norbert Elias' theoretical model - "Social Figurative Model" - is then adopted in order to guide this study. Therefore, the article demonstrates how both groups dispute for the achievement of higher power positions, defining strategies of social distinction and disputes involving those relations. The changes witnessed reflect Ibitipoca's rural area as the place of the encounter of distinct temporalities, where the various actors exhibit distinct representations, interests and values.
\end{abstract}

Keywords: Tourism, rural space, social changes, local culture, Ibitipoca. 
O urbano tornou-se, assim, maior que a cidade e que o campo, tornou-se sua síntese contraditória. Mas essa síntese contraditória não eliminou a cidade nem o campo. As suas relações tornaram-se mais complexas. (Umbelino de Oliveira, 2004:44).

\section{Introdução}

As recentes transformações observadas no meio rural contemporâneo têm desencadeado uma série de discussões acerca das "novas" configurações engendradas pelo estreitamento das relações entre cidade e campo, tendo em vista a heterogeneidade social historicamente construída em torno desses espaços e as subsequentes perspectivas de sua análise.

De acordo com Queiroz (1979:163), a relação entre campo e cidade varia de acordo com a sociedade e o momento histórico - sendo necessário, portanto, recolocá-la constantemente sob novas formas - à medida que se dá a penetração de elementos urbanos no campo e a alternância de funções e demandas entre ambos os meios.

Tendo em vista o crescente reconhecimento das funções do espaço rural relativas ao apoio à qualidade de vida e ao bem-estar social das populações urbanas, Abramovay (2000:2) lembra que há conceituações em que "o rural não é definido por oposição e sim na sua relação com as cidades". Assim, as áreas rurais estão crescentemente associadas a atividades orientadas para consumo, tais como lazer, turismo, moradia, prestação de serviços pessoais e conservação da natureza - atraindo, por conseguinte, atores urbanos, enquanto "espaço propício para que suas necessidades materiais e potencialidades econômicas possam ser repensadas a partir da cidade, já que seu espaço tem se consolidado como alívio ou até alternativa para as condições constrangedoras da vida nas grandes cidades" (GIULIANI, 1990:60).

No Brasil, diversos estudos sugerem que o rural não mais se identifica exclusivamente com as tradicionais atividades agrícolas, uma vez que sua característica mais nova está relacionada à pluriatividade - a qual consiste na combinação da agropecuária com outras atividades não-agrícolas, muitas vezes relacionadas ao aumento da procura deste meio como lugar de vida e de recreação num mundo cada vez mais urbanizado. Contudo, muitas dessas pesquisas tendem a superficializar as análises que envolvem o rural contemporâneo, o qual é traduzido em números nem sempre representativos dos processos sociais que permeiam as estruturas que o indivíduo rural vivencia. Neste contexto, a chegada de novos atores às áreas rurais pode ser entendida 
como objeto privilegiado de análise no afã de se compreender a dinâmica das mudanças ocorridas nestes espaços nas últimas décadas, bem como apreender a natureza das relações entre estes e a chamada sociedade urbano-industrial da qual eles são parte.

Ao longo do processo histórico ocidental, o homem, pontuadamente, desloca-se pelo espaço social - seja pelos lastros milenares da movimentação causada por eventos culturais na antiguidade (como os jogos olímpicos), seja em virtude das condições de subsistência. $\mathrm{Na}$ atualidade, contudo, verifica-se a reprodução de tal fenômeno, agora assumindo novas formas sociais, quer seja: as experiências modernas do turismo e do lazer. O fluxo de turistas no espaço rural, notadamente, provoca o fluxo de milhões de pessoas em todo o mundo, sendo que diferentes atores envolvidos neste fenômeno engendram processos sociais consideráveis. Dessa forma, torna-se oportuno pesquisar os efeitos que tais fenômenos estariam conferindo a tais espaços, uma vez que o turismo cada vez mais vem produzindo-os e transformando-os.

Para Filetto (2004:42), a busca pelo rural, via turismo, está relacionada ao apelo nostálgico de um passado rural recente, em que grande parte da população brasileira se distribuía por esses espaços:

O processo de modernização da agricultura brasileira, aliado à industrialização, demandando cada vez mais mão-de-obra, arrancou "violentamente" o homem do meio rural, encaixando-o, muitas vezes, num espaço urbano sem nenhuma referência a este passado, no qual a identidade perde-se. Os últimos 50 anos da história do Brasil aderemse à construção de uma identidade urbana. $\mathrm{O}$ rural contemporâneo surge, então, como meio de suporte à definição deste anseio de identidade, seja por meio do turismo rural, seja pela apropriação de sua cultura (ibid.).

Não obstante, Sabáh Aoun (2003:16) observa que as imagens nostálgicas relacionadas aos destinos turísticos representam a busca pelo "paraíso perdido" no imaginário ocidental, remetendo a "um lugar muito distante no espaço e remoto no tempo, representado pela imagem de um pedaço de terra, na forma de um jardim perfeito, o primeiro endereço residencial do homem”. O paraíso, assim, poderia ser representado a partir de visões arquetípicas, transcendendo aos relatos bíblicos do jardim das delícias, podendo incorporar a imagem de um feudo destinado "a uma sociedade eminentemente agrária" - como outrora foi a medieval -, ou então ser tropicalizado, como na época das grandes navegações. Na contemporaneidade, entretanto, o turismo recolocaria o indivíduo em contato com o paraíso perdido, materializando - e vendendo - a idéia do retorno às origens humanas: 
O paraíso no universo do turismo não é mais um sonho impossível ou outra utopia fantástica, inventada em pleno século XX. [...] A angústia do homem moderno e a complexidade dos cenários da vida urbana, entre outros fatores, fazem com que o homem institua, como sinônimo de sua libertação desse cotidiano indiferente e impassível, numerosos e variados lugares criados com essa finalidade (AOUN, 2003:26).

Face à degradação da qualidade de vida nos grandes centros urbanos, novas demandas sociais induzem à procura por "refúgios" como alternativa à fuga do cotidiano das metrópoles, sendo que, para alguns autores, "a especificidade do rural é definida em oposição à imagem da cidade, e suas representações são construídas a partir do olhar urbano para o rural"3. Tal oposição, contudo, não foge à perspectiva dicotômica observada por Martins (1981) ao analisar a relação cidade/campo - estes enquanto componentes de uma dualidade social -, entendendo o rural enquanto universo sui generis.

De fato, as práticas culturais expressas nas variadas formas de uso e apropriação de tais territórios congregam, muitas vezes, diversificados saberes patrimoniais crescentemente associados às diferentes maneiras pelas quais o rural é visto, representado e apropriado pelas sociedades contemporâneas. Nas últimas décadas, inúmeras pesquisas se propuseram a apreender e interpretar os significados econômicos das múltiplas funções que o rural vêm apresentando. $O$ fato é que pouca atenção tem sido despendida para se analisar os processos sociais desencadeados pelas atividades não-agrícolas no rural, à medida que estas se expandem por territórios até então voltados a funções eminentemente agrárias.

A partir dessas considerações, e tendo em vista as peculiaridades que permeiam o processo turístico na Serra de Ibitipoca, MG, o presente artigo discute a transformação da vida social local a partir da análise de dois aspectos de sua organização: a reestruturação da esfera produtiva e a chegada de novos atores sociais. Para tanto, são comparados dois momentos da dinâmica social - antes e após a chegada dos primeiros turistas. A partir dessa referência é que são analisadas as mudanças que o turismo confere ao lugar, em termos comparativos.

Contudo, não se trata aqui de apenas discutir as mudanças adaptativas que uma nova atividade econômica - o turismo - causa às populações locais, mas percorrer o caminho oposto, conforme a proposta metodológica levantada por Martins (1993:64),

\footnotetext{
Mathieu apud Rodrigues (2001:16).
} 
conferindo aos atores rurais em questão a condição de sujeitos do processo social e histórico - o que dispensa eventuais vitimizações.

Espaço rural, demandas urbanas. Turistas urbanos, paisagens rurais. Até quando essa dualidade corrobora para a reconstrução da relação campo-cidade? Como articular, no tempo e no espaço, diferentes formas de apropriação da terra, tendo em vista que, segundo Claval (2001:40), “os indivíduos e os grupos não vivem os lugares do mesmo modo", à medida que diferentes aspirações, significados e percepções permeiam um mesmo território? Estaríamos diante da profecia lefebvriana (2004:17) de que os desdobramentos da "práxis urbana" produz seus efeitos sobre diferentes espaços, levando ao subsequente predomínio da cidade sobre o campo à medida que "o tecido urbano prolifera, estende-se, corrói os resíduos de vida agrária” ?

A complexidade de tais problemáticas, de fato, aponta inúmeros temas a serem explorados. Todavia, não se trata aqui de rediscutir os efeitos do turismo na espacialidade local via mercantilização das paisagens ou das culturas - mesmo por que outros estudos têm se dedicado ao assunto. Propõe-se, contudo, repensar as intervenções do fenômeno turístico nos destinos visitados, recolocando os eventuais papéis que as populações locais têm sobre sua expansão pelos territórios.

Nesta perspectiva, torna-se oportuno delinear estudos que investiguem os desdobramentos socioculturais dessa atividade em comunidades rurais ${ }^{4}$ receptoras, privilegiando-se o estudo do turismo enquanto fenômeno sociocultural, enfocando aspectos como a relação entre os visitantes e os visitados (populações locais), bem como as conseqüências daqueles sobre estas - e vice-versa -, a partir da idéia de que as populações afetadas impõem limites e obstáculos à expansão turística, à medida que "o processo econômico encontra pela frente barreiras sociais e ideológicas que conformam a reprodução do capital e as relações de poder dele originadas" (MARTINS, 1993.:66).

Do ponto de vista sociológico tomaremos a noção de "figurações sociais", de Norbert Elias, observando as dinâmicas que organizam o movimento da figuração ${ }^{5}$

A expressão "comunidade rural" ora utilizada tem por base as reflexões de John Comerford (2005:112), segundo o qual o termo se refere a um grupo que se organiza a partir de "relações de proximidade e solidariedade, em que sobressaem a importância de parentesco, vizinhança, cooperação no trabalho e co-participação nas atividades lúdico-religiosas" - características diagnosticadas em Ibitipoca MG.

5 Veremos, na seqüência, que a diferenciação ocorrida na estrutura ocupacional da comunidade, aliada à intensificação dos conflitos entre os antigos moradores "nativos" e os recém-chegados "forasteiros", alteram significativamente aspectos da dinâmica social local, reconfigurando assim as estratégias de reprodução social das famílias no espaço em questão. 
"nativo-forasteiro" ora analisada, interpretando narrativas específicas de turistasveranistas (“outsiders") e nativos (“estabelecidos”) individualmente e em grupo reconstruindo, a partir de uma inflexão histórica, a gênese do turismo na Serra de Ibitipoca. O conceito de figuração, por sua vez, fundamenta-se a partir do binômio indivíduo-sociedade - enquanto componentes indissociáveis de uma mesma estrutura onde "cada ser humano assemelha-se aos outros e é, ao mesmo tempo, diferente de todos os outros":

Seres humanos singulares convivem uns com os outros em figurações determinadas. Os seres humanos singulares se transformam. As figurações que eles formam uns com os outros também se transformam. Mas as transformações dos seres humanos singulares, e as transformações das figurações que eles formam uns com os outros, apesar de inseparáveis e entrelaçadas entre si, são transformações em planos diferentes e de tipo diferente (ELIAS, 2006:26).

Ademais, tem-se enquanto premissa o caráter originalmente processual do turismo, concebendo-o enquanto fenômeno que não se explica pela sua própria manifestação. Para entendê-lo, faz-se necessário analisar a partir de seu conteúdo e tema específicos, olhar além do ambiente disciplinar particular. Sendo assim, propõe-se a narrativa histórica do turismo no lugar enquanto um processo de intervenção nãoplanejado, tendo em vista que a natureza do fenômeno turístico, por si só, implica a desorganização/intervenção socioespacial nos destinos visitados, uma vez que

As ações humanas produzem conseqüências não desejadas, os processos de integração e desintegração de unidades sociais, são sempre virtualidades, possibilidades abertas; pacificação e violência; civilização e colapso da civilização são as duas faces do Jano que envolve a existência humana. A compreensão da crença no progresso deve se completar com a compreensão da fragilidade e do desamparo que envolvem o crescimento permanente das interdependências e a intensificação das tensões entre os seres humanos (NEIBURG; WAIZBORT, 2006:17).

O convívio, na pequena Conceição de Ibitipoca, de pessoas de variadas origens geográfico-culturais, conferem ao lugar a característica de concentrar num pequeno espaço, referências culturais distintas - um "mosaico" em termos de heterogeneidade social. Tal diversidade contribui para colocar em relevo problemas estruturais e conflitos vividos entre os antigos habitantes "nativos" e os recém-chegados "forasteiros", a partir de diferentes formas de apropriação do território, sendo que "para 
além das dificuldades da convivência cotidiana, os conflitos refletem o confronto entre concepções distintas a respeito do que é o rural e os usos que podem ser dados a tais espaços" (WANDERLEY, 2000: 99).

As tensões e polarizações entre "forasteiros" e "nativos" expressam antagonismos intergrupais em nível local, conseqüência da contínua mudança nas estruturas econômicas e sociais provocadas pelo turismo. Por conseguinte, ambos os grupos disputam para seus membros as posições sociais de poder mais elevado, as quais nem sempre são pautadas em critérios econômicos, mas numa combinação de fatores. Tais processos revelam não uma tendência unilateral de desintegração de antigas formas sociais, mas a sua recomposição em novas bases, sua reconstrução face às novas condições de vida.

Assim, a chegada do outsider em Ibitipoca e a concomitante implementação do turismo na região indicam o início de um estágio não-agrícola, de prestação de serviços pessoais, ao passo que resistem, simultaneamente, resquícios das formas de vida social geradas num período anterior - constituindo, tais contradições, um mesmo processo. É possível que tais constatações, de certa forma, remetam à perspectiva lefebvriana, segundo a qual

O mundo atual oferece à observação e à análise, a coexistência de
formações de épocas e datas diferentes [...] essa justaposição
paradoxal - o mais arcaico ao lado do ultra-moderno - é observada
algumas vezes em um território restrito [...] No mundo rural, ainda
mais nitidamente do que no artesanato, nada desapareceu
inteiramente. E apenas o fato dessa conservação de arcaísmos e de
"fósseis sociológicos" - conservação relativa, que não exclui as
influências, as degenerescências, as integrações mais ou menos bem
sucedidas do arcaísmo aos conjuntos recentes(LEFEBVRE,1981:166).

Não obstante, vale registrar, no âmbito da geografia agrária, as contribuições de Umbelino de Oliveira (2004:55), no sentido de que "o urbano como ideologia capitalista hegemônica invadiu todo o rural, porém não o destruiu. Ao contrário, trava com ele relações contraditórias". Nossos estudos, de certa forma, vêm ao encontro das teorizações deste autor, onde a interdependência mútua entre a cidade e o campo conforma uma "unidade contraditória".

Tendo em vista que a bibliografia de pesquisas que contemplem abordagens socioantropológicas envolvendo turismo e populações locais apresenta-se incipiente no Brasil - uma vez que o objeto dos estudos turísticos está quase sempre centrado no turista e nos interesses da indústria que vive das viagens (KRIPPENDORF, 2003:68) - 
propõe-se um olhar dos "indivíduos visitados" sobre os processos em questão. Se não há reflexão teórica acumulada sobre o assunto, traz-se um estudo de caso que se abre à realidade social, levantando questões e problematizando-as a partir da natureza transescalar dos fenômenos observados no "microcosmo" social de Ibitipoca.

\section{Breve histórico socioeconômico da Serra de Ibitipoca ${ }^{6}$}

Um dos primeiros marcos da colonização dos bandeirantes na parte meridional do território mineiro, a história da ocupação colonial na Serra de Ibitipoca remonta ao final do século XVII. Situada ao sopé da montanha, a vila de Nossa Senhora da Conceição de Ibitipoca compreende assim uma das povoações mais antigas de Minas. Por se configurar numa das principais rotas de contrabando do ouro, em épocas setecentistas ordens régias restringiram a abertura de caminhos que perpassavam pela serra, resultando no relativo semi-isolamento geográfico e cultural com o qual a população de Conceição de Ibitipoca conviveu durante muitas décadas (DELGADO, 1962:22).

Ao contrário do que aconteceu com outros lugarejos da região, o aglomerado de Ibitipoca não foi assistido pela malha ferroviária nas primeiras décadas do século XX, a qual perpassava a dezenas de quilômetros do arraial, em função das limitações impostas pelo relevo serrano e à pouca representatividade econômica e política do distrito ${ }^{7}$. Nesse contexto, a população rural $^{8}$ da serra cultivou, ao longo dos séculos, peculiares formas históricas de apropriação e uso dos recursos naturais e do meio rural, baseadas em atividades de subsistência que perduraram até as últimas décadas do século $\mathrm{XX}$ - as quais engendravam modos próprios de organização social, simbologias, mitos e ritos de sacralização do território por parte da população "nativa". Marcos da paisagem natural da serra ainda são lugares de devoção popular; acidentes geográficos como o "Paredão

\footnotetext{
$6 \quad$ O distrito de Conceição de Ibitipoca situa-se na zona rural do município de Lima Duarte, sudeste mineiro. Sua delimitação territorial é definida, em parte, pelas bordas das escarpas da Serra de Ibitipoca.
}

7 A linha férrea Juiz de Fora - Lima Duarte foi inaugurada em 1926, facilitando assim o escoamento da produção agropecuária de pequenas localidades rurais da região (DELGADO:70-9, passim).

$8 \quad$ O uso do termo população rural, neste contexto, se baseia nas seguintes características observadas em Ibitipoca até a década de 1980: sistema de produção baseado em atividades agrícolas com reduzida acumulação de capital; ocupação de áreas predominantemente rurais; noção de território no qual o grupo social se reproduz econômica e socialmente; relativa independência em relação à economia urbana e, conforme lembra Resende (2005:147) uso de linguagem própria pautada em traços de conservação de seu dialeto. 
de Santo Antônio", o "Morro do Cruzeiro" e o "Pico do Pião" possuem significado de "altar natural" onde a população local se reúne tradicionalmente em suas práticas religiosas. Ademais, a órbita da vida social dos chamados "nativos" estava estreitamente vinculada à agricultura, às relações familiares e de compadrio entre os membros do bairro rural ${ }^{9}$, que na época da colheita se mobilizavam em mutirões vicinais:

Aqui vivia da produção do lugar. Tinha só a pequena produção: enxada, foice, o ordenado e a lavoura. Plantava a horta na roça, colhia e comia [...]. Tinha criação de boi, cavalo, leite, produção rural, plantio de arroz, milho, feijão. Ah, eu acompanhava e ajudava a fazer moagem de cana, os meus irmãos tudo foram criado no serviço doméstico que passa ensinado pelos mais velhos, mas obedecendo as ordens na lavoura. As mulheres costuravam, faziam comida e levavam pros camarada na roça. E tinha ainda o mutirão... que era feito assim: o mutirão você marcava pra um dia de sábado, convidava toda a vizinhança, o pessoal da região toda que é uma junta pra ajudar a roçar um pasto, pra capinar uma roça, era muita gente...

(agricultor apostentado, 79)

$\mathrm{Na}$ segunda metade do século $\mathrm{XX}$, contudo, a produção agropecuária local enfrentou dificuldades. Tal contexto está relacionado a uma combinação de fatores tanto micro quanto macroeconômicos, incluindo a conjuntura político-agrícola nacional bem como os efeitos da "modernização conservadora", etc. -, o parcelamento das unidades fundiárias e, posteriormente, a chegada dos primeiros turistas ao lugar - o que engendraria um novo "ciclo econômico".

Assim, a trajetória socioeconômica do distrito começa a se redesenhar a partir da criação do Parque Estadual do Ibitipoca em 1973, por iniciativa exterior à população local. A notável beleza cênica de suas paisagens aliada à riqueza histórico-cultural de seu território lhe conferem um grande potencial "ecoturístico", que desde então atrai milhares de visitantes anualmente. Localizado a apenas $3 \mathrm{~km}$ do parque, o arraial de Conceição de Ibitipoca catalisa grande parte do fluxo de turistas, uma vez que apresenta-se como eixo principal de escoamento e suporte dos visitantes. Em épocas

\footnotetext{
9 Em recente pesquisa, Bedim (2005) observa que o termo "bairro" em Ibitipoca aparece na narrativa dos agentes locais como referência a determinada porção territorial rural à qual se sentiam pertencidos. Neste sentido, Candido (2003:84) lembra que o conceito de bairro nas sociedades caipiras conota certo "sentimento de localidade" entre os moradores cuja convivência era decorrente da necessidade de cooperação e da proximidade geográfica entre eles. Assim, o bairro rural da "Serra Grande" representa um fator territorial integralizador, constituindo-se uma unidade geográfica construída na relação de vizinhança e no sentimento de localidade.
} 
como carnaval e semana santa, a vila assiste à concentração de milhares de turistas, intensificando o contato entre estes e a população local.

A partir dessas considerações, estabeleceu-se a seguinte problemática: Quais as eventuais mudanças socioculturais decorrentes do turismo no lugar? Como a comunidade se reorganizou a partir dessa nova atividade econômica? Estaria o turismo interferindo no modo de vida, na cultura e nas tradições da população autóctone? Em que medida?

\section{Estratégias Metodológicas}

Estudo baseado em pesquisa descritiva a partir de um estudo de caso. Com vistas a investigar as características e transformações no cotidiano de um grupo específico, procurou-se, a princípio, alguma técnica de observação direta dos agentes envolvidos que viabilizasse o registro de seus respectivos depoimentos pessoais acerca de sua cultura, suas formas de organização social e sua visão sobre o desenvolvimento do turismo na Serra de Ibitipoca. Para tanto, lançou-se mão da história oral, no intuito de se abordar qualitativamente os processos culturais e redes de sociabilidade que constituem o ente empírico analisado. Neste sentido, as circunstâncias em que foram produzidos os relatos submeteram-se à vigilância metodológica do pesquisador. Dessa forma, apostouse na estruturalidade da história oral, na dimensão social do fenômeno estudado e no papel desempenhado por seus protagonistas: os indivíduos entrevistados e suas interrelações. Os depoimentos apresentados nesse trabalho refletem trajetórias, histórias de vida e experiências pessoais diversas, mas que permitem estabelecer um eixo principal de reflexão em torno dos desdobramentos do turismo no lugar.

No que tange à amostragem, optou-se pela utilização das chamadas amostras intencionais - ou estratégicas - onde a representatividade dos grupos investigados é feita por critérios qualitativos: "Trata-se de um pequeno número de pessoas que são escolhidas intencionalmente em função da relevância que elas representam em relação a um determinado assunto" (THIOLLENT, 2003:62). Assim, a identificação dos potenciais informantes demandou um levantamento preliminar do contexto socioeconômico e político da comunidade estudada, e foi conduzido de acordo com os objetivos da pesquisa. Como salienta Alberti (1990:14), a escolha dessas "unidades qualitativas" entre os integrantes de determinada categoria requer um conhecimento prévio do objeto de estudo. 
A coleta de dados consistiu, ainda, no levantamento bibliográfico e documental junto à prefeitura e à Câmara Municipal de Lima Duarte, ao IEF - Instituto Estadual de Florestas/MG, à Fundação João Pinheiro, e às demais instituições correspondentes. Publicações científicas, jornalísticas ou projetos desenvolvidos na área também foram consultados. Efetuou-se três pesquisas de campo, definidas conforme o calendário turístico da localidade e de acordo com a disponibilidade de tempo dos pesquisadores. $\mathrm{Na}$ fase exploratória, permaneceu-se um mês em campo (jan.2005). A segunda experiência in locus ocorreu em março do mesmo ano, durante a semana santa, uma das épocas de maior visitação no parque, quando o arraial recebe grande quantidade de turistas. A terceira e última ida a campo consistiu na aplicação efetiva das entrevistas, no período compreendido entre 06 e 13 de maio.

Os agentes entrevistados compreendem tanto os moradores do arraial de Ibitipoca quanto os proprietários de pequenas glebas produtivas existentes no trecho entre a vila e o parque. Ao todo, foram produzidas dez entrevistas, devidamente gravadas e transcritas. Em seguida, procedeu-se à categorização dos dados, os quais foram agrupados por temática. Logo após, iniciou-se a análise de conteúdo, culminando na produção do texto a partir da articulação entre o material empírico e o arcabouço teórico-metodológico.

\section{A gênese do turismo na Serra: os primeiros turistas nos anos 1970}

Os primeiros turistas começaram a chegar a Ibitipoca no período que compreende o final dos anos 1960 e o início da década de 1970. Uma reportagem do Diário Mercantil (1971:s.p.) registra que, à época, “além de estudiosos e caçadores, os únicos visitantes da Serra são as pessoas acostumadas à prática do campismo, com larga experiência em acampamentos instalados em locais de acesso difícil”.

Não obstante, os relatos orais indicam que os primeiros turistas que aportaram na região são descritos como "aventureiros", "mochileiros", "curiosos", "turistas de barraca", muitos dos quais seriam simpatizantes do movimento hippie - talvez embalados pelo então recente Woodstock, 1968 - aspirantes a uma vida "alternativa", sem maiores exigências mercadológicas em relação ao atendimento e demais serviços que envolvem o turismo. Foi o primeiro contato entre visitantes e visitados; um verdadeiro encontro entre culturas, valores e tradições diferenciados. Pelas entrevistas, os agentes deixam transparecer as diferentes sensações que flutuam entre a curiosidade, 
o medo e a cautela deste "contato etnográfico" - alguns "nativos" inclusive evitavam sair às ruas:

Escondia... Aí quer dizer que era um tipo de medo que o povo tinha mesmo né. E era o turista... Tinha medo e vergonha de até informar as coisa pra eles. [...] Porque nunca mexeu com aquele tipo de gente né, era só criado aqui no arraial, na roça, o povo fica meio acismado, não fica?

(ajudante de serviços gerais, 53)

A partir da divulgação, fomentada pelo IEF, das belezas naturais do parque na imprensa regional, o lugar começou a atrair a atenção de visitantes, bem como de jornais e revistas de diversas partes do país. Os primeiros turistas, assim, foram recebidos pela "hospitalidade típica" que os ibitipoquenses herdaram do contato com os antigos viajantes e mascates.

Visitantes e visitados; turistas e anfitriões: representantes do que Levi-Strauss (1976:55) denominara de "sociedades justapostas no espaço" - apesar de afastadas geograficamente e de cultivar suas peculiaridades históricas, representavam culturas contemporâneas entre si. Mineiramente desconfiados, os "nativos" afirmam que a princípio viam o turismo com bons olhos, muito embora não abrissem mão de sua "cautela histórica" ao receber os visitantes.

Até então, havia poucas pessoas "de fora" residindo no arraial. Gradativamente, os moradores locais se inseriam nas novas ocupações proporcionadas pela atividade turística; de início, as mulheres ganhavam uma nova função: "pensionistas", as quais serviam refeições aos turistas. A partir de $1987^{10}$ - quando da inauguração, no parque, dos equipamentos e instalações para receber os visitantes - ocorre a intensificação do turismo na Serra. A população local começa a engrossar suas reivindicações junto ao poder público no que tange à melhoria das condições de vida: não havia sequer transporte coletivo ainda; a única alternativa possível era depender dos serviços prestados por um dos moradores locais que possuía uma caminhonete; caso contrário, restava somente a esperança pela carona do caminhão de leite. Não obstante, a estrada de chão que ligava o arraial a Lima Duarte estava em estado precário ${ }^{11}$ de conservação.

\footnotetext{
10 O parque esteve fechado à visitação pública entre 1984 e 1987, onde foram implementadas obras de infra-estrutura e equipamentos turísticos.

11 O primeiro ônibus a assistir a população de Conceição de Ibitipoca começou a circular por volta de 1998. A única estrada de acesso a Conceição de Ibitipoca é descrita da seguinte maneira por um jornal regional, em março de 1987: "Estrada apertada, buracos, poeiras, barro. [...] é ir apelando para seu Santo
} 
O Instituto Estadual de Florestas, por sua vez, apesar de equipar o parque para receber os visitantes, resistia em melhorar a infra-estrutura de acesso rodoviário à serra, sob argumentos preservacionistas de que a facilidade do acesso implicaria transtornos ambientais futuros, uma vez que aquela unidade de conservação não poderia receber um grande número de visitantes. Delineavam-se os primeiros conflitos entre o IEF a população local, a qual depositava expectativas na nova atividade econômica.

Os últimos anos da década de 1980 marcam o primeiro "boom" da visitação à serra. Em relação ao número de visitantes, ente 1988 e 1995 registrou-se um aumento exponencial. É o que revela a tabela a seguir:

Tabela 1: Freqüência de Campistas e visitantes no PEIb, 1988 - 95.

\begin{tabular}{|l|l|l|l|}
\hline Ano & Visitantes & Campistas & Total \\
\hline 1988 & 4344 & 3288 & 7632 \\
\hline 1989 & 5500 & 4594 & 10094 \\
\hline 1990 & 7350 & 4975 & 12325 \\
\hline 1991 & 7458 & 4424 & 11882 \\
\hline 1992 & 7803 & 3973 & 11776 \\
\hline 1993 & 15452 & 2187 & 17639 \\
\hline 1994 & 16583 & 0 & 16583 \\
\hline 1995 & 2998 & 36793 & 39791 \\
\hline
\end{tabular}

Fonte: IEF/1996.

Cabe ressaltar que o camping do parque esteve fechado entre julho de 1993 e dezembro de 1994, o que consequentemente levou os turistas a se hospedarem no arraial de Conceição de Ibitipoca, intensificando assim o contato e as interações socioculturais entre estes e os "nativos". No ano seguinte (1995) é registrado um aumento expressivo (240\%) nos índices de visitação, contabilizando quase quarenta mil turistas em 1995. O turismo na Serra vislumbrava, pois, o seu "auge". Contudo, a situação estava fora de controle: barracas por todos os lados, acúmulo de lixo, falta d'água, barulho, uso de drogas, brigas, tumultos. Neste contexto do "caos", a população local começa a acenar

de plantão e após, na subida da Serra, é mesmo o seja-o-que-Deus-quiser". (TRIBUNA DE LIMA DUARTE, 22 mar. 1987). 
reativamente $^{12}$ : em 1993 é criada a AMAI - Associação de Moradores e Amigos de Conceição de Ibitipoca, que já em 1994 se mobiliza em torno da criação da campanha de slogan "Salve o Arraial", cujo objetivo principal era a melhoria da qualidade de vida no distrito frente aos danos causados pelo turismo. Segundo o jornal Zona da Mata (1994: s.p.), de pronto a AMAI reivindicou a proibição de acampamento nas ruas de Conceição, bem como adotou medidas de segurança que resguardassem a população local durante os feriados. O mesmo periódico descreve a situação:

Principalmente após os feriados prolongados, quando a população do arraial chega a dobrar, qualquer um pode ver lixo aos montes, bem no meio das ruas, e ainda fezes e o cheiro da urina que ficava no ar, principalmente quando era permitido acampar em qualquer lugar do arraial (ibid.).

Os fatores socioculturais influenciáveis pelo turismo geralmente são os mais difíceis de se quantificar e medir, sendo "altamente qualitativos e subjetivos por natureza" (COOPER et al., 2001:213). Para Lickorish e Jenkins (2000), uma das maiores dificuldades na identificação desses impactos se deve ao fato de eles demorarem um certo tempo para emergir. Segundo estes autores, o impacto do turismo em uma comunidade se relacionam ao volume de turistas que a visitam e à dispersão sazonal dos mesmos. Em Ibitipoca, a sazonalidade ${ }^{13}$ da demanda turística é um fator bastante influente, uma vez que os picos de visitação se concentram nos feriados prolongados como carnaval, semana santa, e revéillon. Contudo, a análise do fenômeno turístico na área estudada não deve considerar apenas o turista enquanto fator influente no processo, mesmo porque a estada do mesmo no arraial se dá por pouco tempo. Não obstante, observa-se que a partir do primeiro "boom" do turismo na serra, não foi somente o número de visitantes que aumentou. Juntamente com os turistas, a região passou a atrair pessoas que fixaram residência no lugar. A esses novos ibitipoquenses atribuiu-se o nome de "forasteiros", os quais foram inseridos no sistema social local.

12 Em abril de 1991, a revista Prática Hospitalar descreve que na época havia uma placa na entrada do arraial com o seguinte aviso: "Você está chegando em Conceição de Ibitipoca. Comunidade com quase 300 anos. Respeite nossas tradições e costumes..."

13 A sazonalidade da demanda turística se caracteriza pela "concentração de turistas em certas localidades em determinadas épocas do ano por sua ausência quase total em outras, provoca transtornos e efeitos econômicos negativos consideráveis nas localidades receptoras" (RUSCHMANN, 2001:45). 


\section{A reestruturação da esfera produtiva e seus desdobramentos sociais}

Conforme abordado anteriormente, até a década de 1970 há indícios de que o sistema de produção da população rural da Serra de Ibitipoca baseava-se em atividades de subsistência, a partir do qual aquele grupo social se reproduzia econômica e socialmente. Entretanto, na segunda metade do século XX a atividade agrícola passava por dificuldades, devido, como já exposto, a uma combinação de fatores. A instabilidade das formas tradicionais de produção agrícola aliada à criação do parque vêm conferir a Ibitipoca novas alternativas econômicas, não apenas pelo fato de o IEF empregar mão-de-obra local: de forma concomitante, os primeiros anos da década de 1970 marcaram o advento do turismo na região. A introdução dessa nova atividade na economia local engendrou mudanças significativas na dinâmica social da comunidade estudada, o que abordar-se-á a seguir.

Desconfiados, a princípio poucos "nativos" se arriscaram na exploração das novas possibilidades econômicas. Os homens continuavam a trabalhar na agropecuária, ao passo que algumas mulheres ${ }^{14}$ gradativamente ganhavam uma nova função: de donas de casa, passaram a servir almoço aos turistas. De acordo com relatos, o turismo a priori proporcionava à mulher uma complementar fonte de renda e, posteriormente, propiciaria a sua inserção no mercado de trabalho - o que até o momento a história havia lhe negado:

Lá [na pousada] eu trabalhei três anos. Com esse dinheirinho que eu ganhei lá, esse guarda-roupa aqui foi o primeiro guarda-roupa que eu comprei com o primeiro salário. Aí que eu fiz os meus quartos.

("Pensionista" e ex-cozinheira de pousada, uma das primeiras mulheres assalariadas de Ibitipoca, 60)

Camareiras, cozinheiras, "caseiras", faxineiras - eis algumas das novas ocupações que a atividade turística, de pronto, atribuía à mulher. Algumas começaram a fazer suas quitandas e a vender produtos locais por conta própria aos turistas. Entre os quitutes produzidos, um destaque para o típico pão folhado, o qual os turistas rebatizaram como pão-de-canela. Em meados da década de 1980, alguns ibitipoquenses alugavam suas próprias casas para turistas durante os feriados, quando se "espremiam" nas casas dos parentes. Conforme pontua Rodrigues (2001:58), o turismo paulatinamente alterava a

$14 \quad$ Na visão de Rodrigues (2001:58), “as senhoras que estavam acostumadas a cozinhar para alguns viajantes que passavam pelo arraial começaram a servir refeições para os turistas". Elas se autoidentificam como "pensionistas". 
rotina das famílias que até o momento "sobreviviam basicamente dos parcos lucros proveniente de uma atividade agropecuária de pequeno porte".

Avançando cronologicamente, já nos primeiros anos da década de 1990 os "nativos" se voltaram às oportunidades que a nova atividade proporcionava, e aos poucos foram aprendendo novos ofícios vinculados direta ou indiretamente ao turismo: à medida que incrementava-se a especulação imobiliária na localidade, a maioria dos homens se inseria gradativamente nos afazeres da construção civil, ao passo que o serviço "pesado" do roçado começava a ser preterido. Aos poucos, foram trocando a enxada da lavoura por outras funções ligadas à prestação de serviços em turismo: trabalhando como caseiros de residências secundárias, guias turísticos, comerciantes, ajudantes de pedreiro, recepcionistas, etc. Alguns começaram a ampliar as próprias casas e a transformar essas extensões domiciliares em leitos para hospedagem.

Com a crescente exposição das belezas da Serra na mídia nacional, aquece-se o processo de especulação imobiliária na região, que por sua vez traz novos significados e configurações ao espaço rural: se antes o poder estava associado à posse de terras férteis e agricultáveis, com o turismo outros parâmetros de poder e valorização da propriedade rural emergem - as unidades fundiárias que possuem os melhores atrativos turísticos, vista panorâmica ou localização estratégica exponenciam seu valor. Terrenos dantes desprezados por serem pouco produtivos à agropecuária de repente são sobrevalorizados a partir de uma demanda externa à população local.

Somando-se a este contexto o fato de que a porção de terreno agricultável para cada família se encontrava cada vez menor em função das partições fundiárias decorrentes de parcelamentos de caráter hereditário, parte da população local não vislumbrou outra opção senão lotear suas terras e vendê-las para quem intencionava estabelecer empreendimentos turísticos ou construir casas de veraneio na serra. Alguns dos que venderam seus sítios e fazendas mudaram-se para cidades vizinhas ${ }^{15}$.

Assim, os mutirões, as antigas relações de compadrio, o jongo ${ }^{16}$ e as demais manifestações culturais ligadas ao modo de produção agrícola estavam igualmente

15

Por outro lado, o desenvolvimento da atividade turística na localidade fez com que alguns dos moradores que haviam se mudado para cidades vizinhas na décadas que precederam o turismo retornassem à serra.

16 Como já abordado, o jongo traduzia o sentido de cooperação existente entre os camponeses ibitipoquenses, os quais reuniam-se em mutirões para colaborar na colheita dos vizinhos. 
comprometidos. Neste sentido, ao ser perguntado se o turismo havia influenciado na perda destas tradições, um agricultor local expõe o seu ponto de vista:

Muito, ué, ajudou muito, uai. Porque nessa parte o turista acabou acabando, implantou outra criação, outro desenvolvimento popular no lugar. O povo tá usando muita tudo, não tem mais mutirão, não tem nada...nem gente pra trabalhar [na roça] mais não tem. O povo mudou pra cidade, civilizou, os mais velho tão acabando...

(agricultor aposentado, 79)

Se num passado predominantemente agrário era comum famílias inteiras servirem a um só patrão ou a si próprias (modo camponês de produção), com o turismo as alternativas se diversificam, ao passo que aumenta a individualidade e a competição entre membros do próprio grupo. Contudo, isso não implica dizer que, ao contrário do que ocorria na Ibitipoca agrária de outrora, a família desempenhe um papel reduzido como unidade socioeconômica - muitos menos se pode afirmar que o campesinato no lugar se dissolveu, simplesmente. Embora a dinâmica social gradativamente se desvincule das atividades agrícolas, a família continua a desempenhar importante função socioeconômica. Observa-se, em alguns casos, que o recrutamento da força de trabalho para o turismo se dá a partir das antigas relações de parentesco e que, ainda, a "pluriatividade" do trabalho pode ser entendida, muitas vezes, como estratégia de permanência dessas famílias na terra. No mais, os "nativos" que possuem negócio próprio geralmente empregam mão-de-obra familiar ${ }^{17}$.

Outro fator observável na fala dos agentes é que o turismo intensificou o contato dos "nativos" com "o mundo lá fora". Com o capital proveniente da nova atividade os ibitipoquenses começaram a ter mais acesso aos meios de comunicação de massa, às leis, direitos e informação de um modo geral. Adquiriram televisão, vídeo-cassete, rádio etc. Tal acesso trouxe consigo outros efeitos e conquistas: entre eles, é apontada a previdência social - segundo relatos, até a década de 1980 eram raros os "nativos" que pagavam algum tipo de contribuição previdenciária. Contudo, com a oferta de trabalho não-agrícola, muitos jovens se esquivam das atividades agrárias, comprometendo a reprodução do modo de vida preexistente:

17 Dados da Fundação João Pinheiro revelam que entre 4 de mar. e 23 de abr. de 2000 cerca de $4,79 \%$ dos turistas hospedaram-se em dormitórios nas casa de família. A maioria destes turistas possuía renda inferior a R\$1000,00. (FJP, 2000:106). 
A mão-de-obra rural não tem. E hoje a agricultura a homem, a puxar enxada, nunca mais produz nada.[...] Óh, [o jovem] depois que estudou, que pega escola, fica lá pra rua caçar emprego. Não querem pegar o serviço pesado não. Lá [na vila] fica vagabundando... Os turista dá serviço pra eles, manda fazer uns aterro, capinar, uma coisa assim...paga bem, um exagero.

(Agricultor aposentado, 79).

Outro agente expõe que os trabalhadores agrícolas estão em condições de desvantagem em relação aos que se "renderam" à atividade turística, uma vez que a prestação de serviços ligados ao turismo lhes provê melhor remuneração. Os mais jovens, seduzidos pelas "facilidades" das novas ocupações trazidas pelo turismo, abandonaram quase que por completo as atividades da agricultura ${ }^{18}$. Algumas hipóteses: i) Como o perfil dos turistas que visitam a serra é composto predominantemente de juvenis ${ }^{19}$, não demorou muito para que os jovens "nativos" absorvessem alguns de seus hábitos, costumes e modismos, os quais eram discrepantes daqueles da Ibitipoca rural de outrora; ii) O turismo possibilitaria um maior acesso ao trabalho assalariado, o qual "permite uma acumulação individual que torna-se o símbolo da autonomia, principalmente para os jovens, em relação à autoridade familiar" (CARNEIRO apud RODRIGUES, 2001:60). A nova atividade, por sua vez, exigia dos moradores locais aprimoramento e profissionalização do atendimento, o qual deveria tender à padronização, com vistas a atender uma demanda cada vez mais exigente:

Com essa vinda do turismo a gente teve que começar a se profissionalizar, aí começou ao longo desse tempo...começamos a arrumar a pousada porque o público da cidade era cada vez mais exigente $[\ldots]$ porque o público que vinha começava a exigir. E foi esse público que foi transformando Ibitipoca.

(dona de pousada, 42)

Essas transformações na estrutura de trabalho através da inserção de ocupações não-agrícolas engendraram uma série de mudanças na dinâmica social local. $O$ cotidiano, aos poucos, parece se distanciar daquele modo de vida marcado pelas

\footnotetext{
18 Neste sentido, Resende (2005) sinaliza que o advento do turismo trouxe novas perspectivas para a comunidade, atingindo diretamente os jovens, "que nos dias atuais não precisam mais deixar sua comunidade em busca de emprego ou mesmo trabalhar na lavoura, como vinha acontecendo anteriormente".
}

19 Segundo pesquisas da Fundação João Pinheiro, 58,57\% dos turistas de Conceição de Ibitipoca estão na faixa etária entre 16 e 30 anos (FJP, 2000:100). 
relações intensas com os recursos naturais e estratégias de uso destes. De calendário agrícola ao calendário turístico: se antes os agricultores guiavam suas ações pela observação das estações do ano ${ }^{20}$ e das fases da lua, agora é o "calendário turístico" que conduz o tempo de trabalho. Um simples feriado municipal de cidades como Rio de Janeiro ou Juiz de Fora pode ser suficiente para levar milhares de turistas a visitarem a Serra. Além do mais, outrora a observância das condições climáticas indicava a época mais propícia ao plantio ou à colheita, de acordo com a alternância entre períodos chuvosos ou "secos." Com o turismo, porém, a chuva é até mesmo preterida pelos ibitipoquenses, uma vez que o barro costuma interditar a principal via de acesso dos turistas à serra - uma estrada de chão em precário estado de conservação.

Os turistas trazem consigo na bagagem o capital oriundo dos grandes centros urbanos $^{21}$, o qual provoca seu efeito multiplicador na economia local. Dessa forma, o tempo de trabalho da população autóctone passa a ser ditado por fatores externos, criando uma relação de maior dependência para com a economia urbana - uma vez que os turistas provenientes das cidades precisam visitar e consumir o espaço rural.

Tendo em vista que o produto turístico é produzido e consumido ao mesmo tempo - o que demanda maior dedicação e mão-de-obra para atender às necessidades dos turistas - é observável a dedicação quase que integral dos prestadores de serviço do turismo em dias de feriado prolongado. Neste sentido, Rodrigues (2001:60) aponta para a "especialização não agrária do trabalho". Tal constatação, contudo, reduz a margem de tempo disponível às práticas culturais ${ }^{22}$, uma vez que os picos de visitação coincidem com as épocas das maiores celebrações religiosas (semana santa, Corpus Christi e Natal, por exemplo). Assim, a mudança de foco da economia influencia aspectos da religiosidade local; a igreja, aos poucos, parece deixar de ser o centro da órbita social. Um morador aponta que o turismo teria corroborado para desviar a atenção dos "nativos" para com a religião:

20 As estações do ano, neste contexto, remetem à observância da época mais propícia ao plantio ou à colheita, de acordo com alternância entre períodos chuvosos ou "secos."

21 Pesquisas da Fundação João Pinheiro (2000) indicam que cerca de 44,6\% dos turistas de Conceição de Ibitipoca são provenientes de capitais brasileiras, enquanto que apenas $2,8 \%$ são originários de outras zonas rurais.

22 Vale lembrar que o jongo, por exemplo, além de vinculado ao trabalho agrícola, representava ao mesmo tempo uma prática cultural local. 
O turismo veio trazendo coisas que chamou a atenção e tirou a atenção da igreja, entendeu? Anos atrás [...] a única tendência aos domingos era a missa [...] e todos os dias tinha o terço: todos os comerciantes fechavam a venda e vinha assistir o terço. A igreja enchia de gente [...] porque era o que tinha, então chamava a atenção. [...] Os velhos foram morrendo, as velhas foram morrendo e os novos não foram chegando. Então sofreu um abalo, um impacto. Aqui a religiosidade sofreu um abalo, e eu vejo dificuldade...

(produtor rural aposentado e dono de um camping,73)

A reestruturação da esfera produtiva com o advento do turismo também tangencia implicações demográficas: os números seguintes ilustram o "inchaço" que ocorreu no arraial. Em 1991, a população distrito de Conceição de Ibitipoca era de apenas 1036 habitantes, com 293 considerados urbanos ${ }^{23}$. Em dezembro de 2004, dados censitários da AMAI contabilizam 1262 habitantes no distrito, dos quais 614 residem no arraial (área urbana). Ou seja, houve um acréscimo de $210 \%$ da população da vila ${ }^{24}$. Em contrapartida, a população da área rural decresceu aproximadamente $13 \%$ nos últimos treze anos. Com o turismo, acelerou-se o crescimento e a concentração populacional na sede do distrito, ao passo que a área rural tornou-se menos habitada.

$\mathrm{O}$ crescimento demográfico da vila aliado às especulações imobiliárias deflagraram um processo de desfiguração física e cultural de suas características arquitetônicas e paisagísticas. $^{25}$ Construções volumosas e em diversos estilos comprometem a estética do lugar. ${ }^{26}$ Neste sentido, Yázigi (2001) alerta que diferentes lugares turísticos de todo o mundo estão ficando "com a mesma cara", esteticamente estandardizados, uma vez que a arquitetura implantada negligencia a "identidade paisagística" dos lugares. E não foi apenas a paisagem que se reconfigurou neste processo. A legislação municipal também sofreu algumas "adaptações" em função do turismo, conforme expressa o Código de Municipal de Posturas (2000), o qual proíbe a criação de animais no perímetro do arraial. Segundo informações colhidas in loco, essa legislação restritiva se deve ao fato de que os proprietários de pousadas estariam

\footnotetext{
23 Fonte: Fundação João Pinheiro (2000).

24 Atualmente é da ordem de 766 o número de eleitores do distrito de Conceição de Ibitipoca, segundo dados recentes da Prefeitura Municipal de Lima Duarte.

25 Em 1988 havia 130 casas no arraial (VIEIRA, 1988). De acordo com levantamentos recentes da AMAI (dez. 2004) este número subiu para 385.

26 Construções exóticas e em estilo europeizado com direito a "chalés-alpinos-suiços" parecem conferir a Ibitipoca ares de uma segunda Campos do Jordão.
} 
insatisfeitos com o mau cheiro provocado pelos chiqueiros que os nativos mantinham nos quintais. Os donos de pousada alegaram, para tal, inúmeras reclamações de incômodo dos turistas. Entretanto, sabe-se que a criação desses animais é uma prática cultural secular dos ibitipoquenses. Ora, pois, é o turismo que tem que se adaptar à cultura local, e não o contrário. Aliás, a culinária daquela população se baseia na banha de porco, na qual os gêneros alimentícios eram conservados e fritos. Uma agente local manifesta o seu descontentamento, argumentando que antes do turismo

... todo mundo engordava [porcos]. Era só os nativos aí, não tinha esses negócio de pousada, não tinha essas indústria maior...então todo mundo engordava o seu porquinho, criava terreiro de galinha, as galinha pastava grama na rua. Era tudo bom. [...] Ah, isso foi uma lei muito boba, porque os porcos dava futuro pra gente né. Pelo menos eu já engordei muito porco aqui no meu quintal. Foi uma lei boba... é uai, isso é uma lei boba! Mas foi proibido mesmo, porque aqui tinha várias pessoas que engordava [porco] no centro, ali em baixo perto de pousada e tal...aí eles foram proibindo, dando dinúncia [sic] até vim essa lei. Mas isso foi uma lei muito boba, porque aqui o lugar não era uma cidade grande. Agora, numa cidade grande tá certo porque dá inseto, dá catinga, dá isso, dá aquilo. Nós engordava era dois, três porco e depois eles proibiram... por causo do inseto em pousada. Só por causo disso.

(dona-de-casa aposentada, 65)

Para Inskeep (apud COOPER et al., 2001:208), a magnitude dos efeitos socioculturais do turismo vincula-se ao "grau de diferenciação das características dos anfitriões e visitantes", incluindo o sentido de organização do tempo. No caso de Ibitipoca, os agentes entrevistados apontaram haver certa discrepância entre a temporalidade dos moradores do lugar e a dos turistas, como se estes reproduzissem uma temporalidade acelerada, o que influenciaria diretamente no cotidiano da comunidade:

Ah... antigamente era mais tranqüilo né. [...] Tenho saudade... porque a gente vivia naquela paz louca né... e o negócio de turismo é muito corrido né... Já trabalhei muito em pensão, trabalhei na pensão da minha irmã quás quatro anos, trabalhei na pensão da sobrinha ali assim também... e o negócio é muito corrido, sabe.

(dona-de-casa aposentada, "ex-tecedeira", 65)

Acrescentar-se-á a todas essas colocações as alterações observadas nos padrões de consumo da população local, que com o declínio da produção agrícola se viu mais dependente do mercado urbano, consumindo mais produtos da cidade. 
Concomitantemente, os relatos dos moradores indicam que o turismo provocou uma possível elevação de seu custo de vida ${ }^{27}$ - os produtos comercializados no local ficaram mais caros, o que comprometeria a qualidade de vida dos "nativos". Além disso, o fato de Ibitipoca reconfigurar suas formas de produção e caminhar atualmente para o desenvolvimento de uma "monocultura turística" 28 é no mínimo preocupante devido ao caráter sazonal dessa atividade.

Aqui tem muita gente vivendo do turismo. Essas pensão, esses hotéis, essas coisa assim só utiliza, só tem renda depois que recebe os turismo vem aí nos feriado e vai embora, compreendeu? Não tem outro meio de vida. Então se acabar o turismo o empate, o investimento que eles fez desvaloriza, volta, perde o valor e não tem mais valor, eles não têm manutenção, não tem meio de vida...não tem ninguém que quer plantar.

(agricultor aposentado, 79)

Neste sentido, uma alternativa razoável seria a diversificação dos meios de produção, aliando o turismo e a produção agrícola enquanto atividades complementares, não concorrentes. Outrossim, pelas observações de campo supõe-se que o turismo fez surgir um estrato intermediário emergente, composto por alguns "nativos" empreendedores que "subiram na vida", os quais alcançaram algum sucesso com seu próprio negócio, seja uma pequena pousada, restaurante, bar, camping ou sorveteria.

Contudo, a herança do antigo sistema de produção agrícola ainda deixa seus resquícios, muito embora as mudanças resultantes do turismo induzam os antigos moradores a recompor certas práticas. As tradições rurais insistem em permanecer na memória daqueles que a viveram. Ademais, a reestruturação da esfera produtiva ora descrita está vinculada a inúmeros aspectos de caráter político, cultural e social, incluindo a chegada de novos atores sociais na comunidade estudada. Este e outros efeitos derivados do turismo serão abordados adiante.

\section{A chegada de novos atores sociais: o "outsider" e suas implicações}

Até o final dos anos 1980 havia poucas pessoas "de fora" residindo no arraial. A população constituía-se quase em sua totalidade dos "nativos" que ali estavam

27 Dados fornecidos pela Prefeitura Municipal de Lima Duarte indicam que a renda familiar média em Conceição de Ibitipoca é de R\$ 350,00. 
estabelecidos - os quais se conheciam e tinham um sentido de pertencimento comum àquele lugar. Ao fazer referência aos membros do grupo, os "nativos" se autoidentificam através de expressões como "nós do lugar", "a gente nossa", "nós localizados", "nós nativos", “o povo daqui”.

Contudo, de forma concomitante à expansão do turismo na serra, a região passou a atrair pessoas das mais variadas partes do país - e quiçá do mundo - que fixaram residência no arraial com os mais diversos propósitos: uns buscavam qualidade de vida; outros, porém, chegaram com a intenção de explorar economicamente o turismo. A esses novos ibitipoquenses, atribuiu-se o nome de "forasteiros", os quais chegaram para compor o sistema social local com a característica de serem "os de fora". Neste sentido, Rodrigues (2001:67) os designa como aqueles moradores "recém-chegados, vindos de outras cidades e que possuem residência fixa no arraial", incluindo os "antigos turistas, comerciantes e artesãos que chegaram ao local estimulados, principalmente, pela atividade turística". A autora divide os "de fora" em dois subgrupos: turistas e "forasteiros"; entre "os de fora" incluem-se outras subcategorias, cujos critérios de distinção não são tão simplificados como eventualmente o pareçam. Os que possuem casas de veraneio no lugar mas que não têm vínculos profissionais com o turismo são bem quistos pelos "nativos", assim como os turistas cuja estada no arraial é curta. Dessa forma, há evidências de que haja uma sobreposição da esfera econômica na definição de tais subgrupos, uma vez que os turistas-veranistas além de não competirem com "os do lugar", ainda são fontes de emprego e renda para os mesmos, o que nem sempre ocorre com o "forasteiro empreendedor". Eis uma visão "nativa" sobre os turistas que possuem residência secundária ${ }^{29}$ no arraial:

Ah... eu, pra mim, eu acho que foi bom também. Porque se eles tem as casa aí eles pode dar serviço pras mulher aqui do arraial: uma toma conta, outra faz limpeza né. Então quer dizer que eles dá ganho pro pessoal do lugar. Quer dizer que eles trouxe boa coisa também né.

(ajudante de serviços gerais, 52)

No entanto, a chegada desses novos atores também engendrou uma série de conflitos e descontentamentos por parte da população rural que ali estava estabelecida, a qual manifestara insatisfação e sentimentos de rejeição para com os novos moradores e turistas. À medida que o arraial "inchava" em virtude dessa "migração", aumentava o

29 Neste contexto, as residências secundárias se referem às casas dos veranistas. 
sentimento de rejeição dos "nativos" para com os "recém-chegados". Tal impasse culminou no Movimento Fora Forasteiro, ocorrido em 1995, cujo estopim teria sido uma reportagem publicada numa revista de âmbito nacional ${ }^{30}$, na qual alguns "nativos" se sentiram ofendidos em virtude das declarações dadas por alguns "forasteiros" :

Em represália a todos aqueles que vieram de fora - isso foi uma coisa louca - por exemplo eles jogaram pedra na casa desses turistas que tinham vindo pra cá, em todos os postes estava escrito assim "FORA FORASTEIRO", furaram pneu de jipe... Todas as casas, todas as pessoas que estavam aqui mas que vieram de fora sofreram represália... [...] E foi uma coisa assustadora na época, eu tinha acabado de mudar pra cá. [...] Eles não queriam essas pessoas aqui, eles estavam se sentido invadidos, eles estavam sentido que estavam vindo cada vez mais pessoas e isso é natural de qualquer lugar.

(proprietária de pousada, 42)

Tal manifesto parece ter sido apenas o estopim de uma tensão social que há anos se desenhara, talvez porque os "forasteiros" se apresentavam como os principais investidores locais, e estariam obtendo assim os maiores lucros provenientes da atividade turística. Nas palavras de Rodrigues (op.cit.:68), "os novos moradores do arraial se dedicaram exclusivamente às atividades de serviço ligadas ao turismo". De acordo com suas pesquisas, em 2000 cerca de 55,3\% dos estabelecimentos comerciais e turísticos do arraial pertenciam aos nativos, enquanto que $44,7 \%$ eram de propriedade dos moradores "de fora". Contudo, as observações de campo apontam que esses diferentes atores possuiriam diferentes condições de investimento, sendo os "forasteiros" os detentores dos maiores e melhores meios de hospedagem e restaurantes, concentrando assim a supremacia do capital empregado na atividade turística.

Assim, o turismo e os "forasteiros" inserem uma lógica social externa aos "nativos", intimamente vinculada a questões econômicas de custo-benefício. Antes da introdução desses novos atores naquele "microcosmo", porém, os "nativos" relatam haver condições de "paz", "sossego" e "tranqüilidade" entre eles, projetando nos "de

$30 \quad$ A referida reportagem foi publicada na Revista Manchete de 22/07/1995, a qual tinha o seguinte subtítulo dedicado aos recém-chegados: "Os forasteiros desvendam os mistérios e as belezas do arraial". Entretanto, no único exemplar que conseguimos pesquisar, a página das declarações polêmicas estava danificada. Mas alguns trechos ainda estão legíveis, inclusive o que descreve os forasteiros: "Com ambições e profissões diferentes, todos têm em comum a paixão pela vida tranqüila na serra e a disposição para investir energia e dinheiro naquele pequeno lugar”. Um outro parágrafo deixa transparecer o por que a reportagem causou tanto rebuliço: “... na vila de Ibitipoca, todo mundo sabe de tudo. As novidades se espalham numa velocidade de fazer inveja a qualquer auto-estrada cibernética. Fala-se da vida do outro por falar, por falta de assunto melhor”. (REVISTA MANCHETE, 1995) 
fora" a culpa pelos principais problemas sociais identificados atualmente, bem como a introdução do espírito competitivo entre os membros da comunidade:

Antigamente a gente não tinha quase problema nenhum não né, porque era só a gente do lugar, bem dizer. Com o turismo é que foram surgindo esses problemas. [...] As pessoas se ajudavam um ao outro, era unidos. Hoje cada qual quer ver o outro cair num buraco. Você tá caindo e as pessoa não tem coragem de puxar pra trás, ainda acaba de empurrar.

(Pensionista, ex-cozinheira de pousada, 60)

Neste sentido, Krippendorf (2003:18) assinala que os habitantes das regiões visitadas, em determinado momento sentem um certo rancor ${ }^{31}$ em relação aos efeitos negativos do processo de intervenção social provocado pelo turismo: "Essas populações têm, cada vez mais, a impressão de que são invadidas por esse desenvolvimento e, ao mesmo tempo, dele excluídas".

Conflitos que envolvem relações de poder análogas são observados nos estudos de Elias e Scotson (2000), onde os autores analisam as relações de desigualdade social e diferença a partir das relações sociais entre os estabelecidos e os outsiders numa pequena comunidade industrial inglesa. Assim como os "forasteiros" de Ibitipoca, os outsiders são os estrangeiros que não partilham os valores e o modo de vida vigentes na comunidade dantes estabelecida - no caso, os "nativos". Na condição de estabelecidos, os "nativos" fundariam seu poder a partir do princípio de antigüidade, lançando mão do maior tempo de residência no lugar enquanto fator distintivo em relação aos "outros recém-chegados":

... mas eu estou localizado, e ele [o forasteiro] evém né.

(agricultor aposentado, 79)

Mas ele [o forasteiro] não é daqui. Ele está aqui mas ele não é daqui, ele é de [...] Aqui é que são as minhas raízes [...] A minha mãe é daqui [...] foi nascida aqui, criada aqui, está enterrada aqui, a mãe dela, os irmãos dela estão todos aqui. Então minha raiz é aqui. O meu lugar é aqui.

(produtor rural aposentado e dono de um camping, 73)

Ademais, os "nativos" se auto-identificam como um grupo bastante peculiar, cujos critérios de "superioridade" em relação aos demais vinculam-se ao que Elias

\footnotetext{
31 Vieira (1988) registra que uma "nativa" utiliza a seguinte expressão para manifestar o
} sentimento de invasão que acometia a população local: “A gente se sente hóspede do lugar”. 
denomina carisma grupal distintivo, em detrimento dos aspectos culturais dos "forasteiros":

Eles [forasteiros] não conveve junto diariamente... Nós os nativo não, todo dia tá junto ali né, todo dia. Então tem um tipo de confiança a mais né. [...] Então o turismo veio, veio todo tipo de gente: veio o bom, veio o ruim, veio o maconheiro. O jeito de conversar [do forasteiro], o jeito de lidar né com as pessoa deles são diferente. [...] Sempre os forasteiro é desunido nessa parte né... que eles não tá costumado c'aquele ambiente né. Um causo né, vamo supor: se eu tô brigando com outra pessoa ali, nós aqui do local né, os nativo, vai tentar separar aquela briga e conversar. E eles [forasteiros] se vê acontecer um causo desse eles corre né, não vieram participar daquilo. Os nativo não, aí já é diferente né.

(ajudante de serviços gerais, 52)

Elias e Scotson (op.cit.:22) observam ainda que tais grupos em disputa pelo poder local costumam lançar mão da estigmatização social do grupo oposto como estratégia de hierarquização social a nível local, atribuindo-lhes rótulos e estereótipos que impregnem a condição de "inferioridade humana". Neste sentido, os "nativos" não raro associam os "de fora" como vetores do consumo de drogas no arraial, principalmente a maconha:

A droga tinha que diminuir, não tinha? Tinha que diminuir os turismo... Aqui os vendedor são os turismos que mora aqui; não todos. Porque depois que começou turista a morar na Ibitipoca aí a droga aumentou. Então acha, a gente não fala isso pra poder contrariar eles não, mas os moradores de fora são os maior vendedor. [...] Ibitipoca atrai pessoas que vem de fora que parece que seja bom, mas tem uns que a gente renega, né... nosso lugar mesmo tem vários que a gente renega né, mas vamos tocar? Não vamos. Eles acham o nosso lugar bom pra eles vir morar... Aí a gente fica partido, não sabe o quê que faz...

(Dona-de-casa aposentada, 65)

Com o intenso fluxo de turistas e o aumento do número de moradores "recémchegados", problemas diversos atingiram direta ou indiretamente a comunidade, como acúmulo de lixo nas ruas, transporte coletivo deficitário, falta d'água, excesso de barulho, segurança, etc. Nesta perspectiva, os "localizados" responsabilizam os "forasteiros" e turistas pelos eventuais furtos ocorridos no distrito, atribuindo-lhes também a culpa pelo surgimento de doenças infecto-contagiosas. Por sua vez, os que vieram "de fora" não aceitam ser chamados de "forasteiros" devido ao teor pejorativo do termo, e consideram-se mais instruídos que os "nativos": 
Eu não me acho uma forasteira. Eu me acho muito mais nativa do que muitos nativos daqui. Somos de fato forasteiros, mas aí muitas vezes essa palavra é usada de uma maneira pejorativa. [...] Infelizmente eu acho que quem vem de fora tem muito mais noção do valor desse lugar do que as próprias pessoas que moram aqui, porque pra eles isso é meio normal.

(dona de pousada, 42)

Mas há também critérios de distinção interna entre os "forasteiros". Ao chegarem na comunidade, os que vêm "de fora" são estranhos tanto para os "nativos" quanto para os demais "forasteiros" que ali já estavam; essa condição de duplamente estrangeiros dificultaria a organização social dos "recém-chegados". Possuindo origens diferentes, os "forasteiros" não apresentam coesão enquanto grupo, tampouco compartilham traços identitários em comum - o que intensifica a tensão forasteiro $X$ forasteiro: não raro, uns são acusados por outros de ter propósitos puramente economicistas, cujo objetivo maior ao se mudarem para Ibitipoca seria unicamente enriquecer. Esse tipo de "forasteiro" é identificado como pessoa non grata pelos demais, que por sua vez dizem buscar qualidade de vida em primeiro lugar.

Além do mais, deve-se ressaltar que apesar de os "forasteiros" portarem um padrão de vida aparentemente superior à norma local, eles estão sujeitos às condições de afastamento geográfico que se aplica aos "nativos". Para morar em Ibitipoca, tiveram que abrir mão de certas facilidades propiciadas pelos centros urbanos de onde vieram. E as restrições não são poucas: assistência médica inadequada, falta de alternativas educacionais, economia dependente das circunstâncias externas, intemperismos políticos do IEF, falta de policiamento etc. Tais constatações reforçam a idéia de que as relações de poder em Ibitipoca não são unicamente pautadas em critérios econômicos, mas sim numa vasta gama de fatores como naturalidade, tempo de residência no lugar, identificação e objetivos para com Ibitipoca, entre outros. Sendo assim, relativiza-se o discurso de Barreto (2004:136) de que as diferenças econômicas, o status a nível internacional ou os avanços tecnológicos dos visitantes tornam a relação entre visitante e visitado assimétrica.

Outro fator relevante é que, via de regra, os "nativos" pré-julgam o comportamento do turista de acordo com a procedência deste: os de Juiz de Fora, por exemplo, são rotulados de "farofeiros", "baderneiros". Nos turistas de Lima Duarte, a população local lhes projeta a rivalidade histórica que permeia as duas localidades. Os paulistas, por sua vez, parecem ser bem quistos, bem como os belorizontinos. Por trás 
destes estigmas, no entanto, possivelmente se escondem interesses mercadológicos. Algumas hipóteses: os turistas provenientes de cidades vizinhas como Juiz de Fora e Lima Duarte comparecem em maior número, geralmente gastam menos, trazem comida de casa, usufruem do mesmo transporte coletivo da população local e não necessariamente pernoitam em Conceição de Ibitipoca. Os turistas que vêm de centros mais distantes, por deslocarem-se em distâncias maiores e com automóvel próprio, além de pernoitarem na serra ainda possuiriam maior poder aquisitivo. Contudo, o "fenômeno forasteiro" não é nenhuma exclusividade de Ibitipoca. Ao conceber o espaço enquanto uma das condições da sociedade, Simmel (1983:182) delineia uma discussão teórica sobre $o$ estrangeiro, na condição de pessoa que "chega hoje e amanhã fica", enfatizando as "forças psicológicas" ou "espirituais" que aproximam, unem ou separam os indivíduos e os grupos. Nesta perspectiva, os "forasteiros" de Ibitipoca representam uma forma específica de interação para com o grupo estabelecido, flutuando no viés de serem membros deste grupo ao mesmo tempo que "estão fora dele e o confrontam" :

Eles [os de fora] talvez tenha mais confiança em mim do que eu neles... Porque eles também é estranho de tudo. Eu também sou estranho pra ele, mas eu estou localizado, e ele evém né. O sujeito tem um mucado [bocado] de cisma daquele que vem. Cisma. Medo. É, uai. [...] Eu ainda tenho muita cisma. Mas converso com todo mundo: apareceu, procurou, eu converso.

(agricultor aposentado, 79)

Ainda segundo Simmel, a posição do estrangeiro no grupo "é determinada, essencialmente, pelo fato de não ter pertencido a ele desde o começo, de ter introduzido qualidades que não se originaram nem poderiam se originar no próprio grupo" (ibid.). Neste sentido, as observações empíricas lançam evidências de que os "nativos" de Ibitipoca incorporaram hábitos de consumo e comportamento tipicamente urbanos dos turistas e dos "forasteiros" residentes, o que teria provocado mudanças de valores e condutas morais dos "nativos". De acordo com Levi-Strauss (1976:57) muitos costumes nascem "apenas da vontade de não permanecerem atrasados em relação a um grupo vizinho". Em contrapartida, o mesmo autor ressalta que o efeito inverso pode ocorrer, reativamente, quando a proximidade entre grupos com características culturais distintas pode neles despertar o "desejo de oposição, de se distinguirem, de serem eles próprios" (ibid.). 
Todavia, Simmel sinaliza que as relações de proximidade e distância que envolvem a relação entre o estrangeiro e os membros de determinado grupo é permeada pela acentuação do "de fora" enquanto elemento "não-comum", posição essa que é definida simplesmente pela condição de origem. E acrescenta: "os estrangeiros não são realmente concebidos como indivíduos, mas como estranhos de um tipo particular: o elemento de distância não é menos geral em relação a eles que o elemento de proximidade" (SIMMEL, 1983:187). Tal pressuposto talvez seja a base, por exemplo, do fato de os "nativos" distribuírem os lotes da igreja gratuitamente entre si, ao passo que os "forasteiros" devem pagar aos cofres da paróquia valores que os próprios "nativos" estipulam ${ }^{32}$. Tais critérios de distinção social a partir da naturalidade dos atores são igualmente transpostos para o controle da portaria do Parque do Ibitipoca, já que os porteiros, todos "nativos", lançam mão da condição de origem dos "forasteiros" para justificar que os mesmos, ao contrário dos "nativos", devem pagar ingresso para entrar $^{33}$, uma vez que, apesar de residirem no lugar, "eles não são de lá". Dessa forma, ao contrário do que Elias e Scotson (2000) verificaram em Winston Parva ${ }^{34}$, o tempo de residência no lugar não seria o principal fator distintivo de tais grupos no contexto social do arraial mineiro estudado. Os vínculos territoriais históricos que mediaram a relação dos "nativos" para com a Serra de Ibitipoca ao longo dos séculos talvez impliquem em laços identitários profundos a ponto de forçar à sobreposição do fator naturalidade $e^{35}$ em relação aos demais. Na visão de Silva (2004:24) "o lugar define o pertencimento social, o enraizamento em um determinado território.” Assim, o território não concerne somente ao espaço físico, "mas também ao espaço simbólico, que o envolve com significados da cultura e da vida social ali existente".

32 Os terrenos da vila pertencem à "santa"; os moradores do arraial não têm escritura dos terrenos ou registro dos imóveis, e conseqüentemente não pagam IPTU. Tal situação possui explicação histórica: em 1836 a porção de terra do arraial foi doada a Nossa Senhora da Conceição, "a quem deviam pagar alguma cousa [sic.] os que fizessem casas, pois esta era a condição apresentada pelos doadores" (DELGADO, 1962:113). Atualmente os próprios "nativos" ligados à igreja é que definem a forma de distribuição dos terrenos. Os nativos, por sua vez, ganham os lotes, enquanto que os "forasteiros" devem pagar "à santa" uma quantia por eles.

A portaria $n^{\circ} 36$, de 03 de março de 2003 estabelece normas de visitação das dependências do Parque Estadual do Ibitipoca e institui que os residentes da vila, desde que apresentem comprovante de associados a entidades não governamentais, sem fins lucrativos, existentes e atuantes no entorno do parque, terão isenção da taxa de ingresso, a qual é limitada aos dias úteis, de segunda a quinta-feira (IEF, 2003). Entretanto, alguns "forasteiros" que residem no arraial reclamam que os critérios de naturalidade ainda são utilizados para definir a isenção da taxa de ingresso no parque, uma vez que os funcionários da portaria do parque são todos "nativos".

Winston Parva é o nome fictício da pequena cidade do interior da Inglaterra onde Norbert Elias e Scotson (2000) desenvolveram seus estudos sobre a relação estabelecidos e outsiders - obra antológica publicada pela primeira vez em 1965 .

35 Acrescentar-se-á a tais fatores as relações interparentais favorecidas pela prática da endogamia. 
No mais o convívio, na pequena Conceição de Ibitipoca, de pessoas de variadas origens geográfico-culturais ${ }^{36}$ conferem ao lugar a característica de concentrar num pequeno espaço raízes culturais distintas, como se fosse um "mosaico cultural". Tal diversidade contribuiria para colocar em relevo problemas estruturais e conflitos vividos entre "nativos" e "forasteiros". Dessa forma, as rupturas com padrões culturais tradicionais historicamente estabelecidos sugerem que a interação entre esses diferentes grupos engendre um processo de construção de novas identidades sociais no espaço rural. Mas se a "comunidade" compõe-se de "nativos" e "forasteiros", a mesma apresentaria traços de afirmação, negação ou fusão identitária? A chegada de novos atores sociais faz com que Ibitipoca congregue identidades justapostas no espaço? Haveria uma reestruturação das identidades envolvidas?

Vale registrar que, de acordo com Moreira (2005:19), “a existência de uma identidade requer a existência de outras identidades, tal é essa contingência do relacional. O uno requer o diverso, o indivíduo só existe na relação social. A identidade rural requer a existência do não-rural.” Neste sentido, é possível remeter tais hipóteses ao fenômeno de formação das identidades contemporâneas, caracterizado pela emergência de identidades culturais "que não são fixas, mas que estão suspensas, em transição, tirando seus recursos ao mesmo tempo de diferentes tradições culturais", comuns na era globalizada (HALL, 2005:88). Os "forasteiros", por sua vez, apesar de carregarem consigo fortes vínculos de sua terra natal, "são obrigados a negociar com as novas culturas em que vivem, sem simplesmente serem assimilados por elas e sem perder completamente suas identidades" (ibid.). Assim como os "de dentro", os "de fora" recriam seus próprios vínculos com o lugar. Daquela paisagem já fazem parte; inclusive nela deixam suas marcas, seja nas formas arquitetônicas, seja na toponímia atribuída a muitos atrativos naturais ${ }^{37}$. Assim, paulatinamente, os "forasteiros" deixam de ser estrangeiros no lugar e se tornam estrangeiros do lugar.

\footnotetext{
36 Nos estudos de campo observou-se que os forasteiros são provenientes de variadas regiões e estados brasileiros como RS, ES, PE, RJ, MG, SP, DF e BA, bem como de diversas cidades do interior de Minas. Há ainda, algumas pessoas de outras nacionalidades residindo no arraial: italianos, franceses e uma "colônia" de belgas que há 6 anos mantêm moradia na Serra.

37 Grutas dos Gnomos, Cachoeiras das Fadas, Tibum e Janela do Céu são apenas alguns dos topônimos que "os de fora" atribuíram aos atrativos naturais do Parque Estadual do Ibitipoca.
} 


\section{Considerações finais}

Mas, afinal, quem chega? O capital... personificado na figura do "outsider", do "forasteiro", do "outro", o "urbano estrangeiro" - parafraseando os estudos clássicos de Martins (1993). Concomitantemente, assiste-se à expansão da lógica competitiva de mercado a espaços até então caracterizados por atividades agrícolas de subsistência e peculiares formas de organização social ${ }^{38}$, rompendo assim com a condição de relativo semi-isolamento no qual a população camponesa de Ibitipoca se encontrava.

As subsequentes tensões e polarizações entre "forasteiros" e "nativos" expressam antagonismos intergrupais em nível local, conseqüência da contínua mudança nas estruturas econômicas e sociais. Além disso, as formas de sociabilidade destes atores apontam para a reconfiguração das identidades envolvidas - revelando a Serra como espaço social de trocas simbólicas, cuja diversidade provém da reconstrução de suas bases culturais, refletindo novas relações entre grupos e indivíduos. A partir de sua própria plasticidade, a população local se ajusta ao novo contexto, assimilando elementos culturais externos sem necessariamente perder seus aspectos culturais básicos. Tais constatações indicam a coexistência de temporalidades distintas neste espaço (permanências e rupturas; velhas ruralidades, novas aspirações, etc.) tendo em vista que, em termos lefebvrianos, o tempo de reprodução do capital exige que diferentes coisas aconteçam simultaneamente - quer seja, a Serra de Ibitipoca como espaço turístico envolto pela lógica da simultaneidade.

Devido às suas peculiaridades histórico-culturais, a Serra de Ibitipoca ainda assiste à recomposição de sua dinâmica social em face das mudanças em curso, à medida que há a penetração de elementos "urbanos" e ao passo que seus atores "rurais" se inserem nas esferas mais amplas da sociedade. Isso não implica dizer que o turismo foi ruim ou bom para o lugar. As mudanças são características das sociedades humanas, o que dispensa eventuais vitimizações. Entretanto, a diferenciação ocorrida na estrutura ocupacional da população local alterou significativamente alguns aspectos de sua organização social, introduzindo uma nova ordem competitiva e diversificando as estratégias de reprodução social. A inserção de ocupações rurais não-agrícolas ligadas à prestação de serviços em turismo paulatinamente reestruturam a esfera produtiva local sem, no entanto, extingüir antigos significados da sociodinâmica agrária de outrora. A família continua a desempenhar importante função socioeconômica, e as antigas

38 Referência ao modo de vida camponês e suas respectivas especificidades locais. 
relações de parentesco e compadrio são utilizadas como referência no recrutamento da força de trabalho empregada no turismo. As representações geradas no período anterior ainda encontram-se impregnadas de significado, e parecem reviver na memória daqueles que as conheceram: a agricultura e o jongo, assim, ainda congregam atual valor simbólico.

O olhar exotizante do turista e dos meios de comunicação que divulgam Ibitipoca, por sua vez, definem o camponês a partir de uma noção de ente "primitivo". Ao longo das últimas três décadas, o camponês internalizou essa condição ao absorver uma imagem distorcida de si a partir da representação do turista. O que subjaz esse (des)encontro inicial entre camponeses e turistas é um processo de difusão cultural do estilo de vida urbano - já que, conforme destaca Queiroz (1979: 168), "o gênero de vida burguês ocidental é eminentemente citadino". Subentende-se, nesse processo, a construção de um olhar "urbano" sobre o "rural", em que este último é correlacionado a estereótipos de primitividade - recompondo, de certa forma, antigos traços de dominação verificáveis em configurações macro-escalares que permeiam a relação rural/urbano no Brasil.

Viajar para Ibitipoca passa então a ser uma possibilidade de o turista imergir na alteridade do "paraíso" recém-descoberto, em que imagens fixas dos atrativos naturais são complementadas com representações estereotipadas do "exotismo" expresso no olhar do turista sobre o modo de vida camponês. A principal motivação da viagem, contudo, é definida a partir do apelo estético das paisagens da Serra e os componentes biofísicos e geomorfológicos nela existentes - as cachoeiras, os lagos, as bacias visuais panorâmicas favorecidas pela altitude, os rios, os paredões rochosos, as grutas, a fauna e a flora. A imagem do camponês é enunciada apenas a título de identificação secundária do destino, um componente a mais do cenário Ibitipoca.

Nesta perspectiva, as figurações engendradas a partir da interação cidade-campo, via turismo, não devem ser concebidas apenas como situações sociais mediadas por uma atividade econômica, e sim como um complexo processo de intervenção socioespacial capaz de alterar estruturalmente o cotidiano dos lugares. A partir do momento em que tais mecanismos de intervenção são conhecidos, podemos ampliar o entendimento sobre as relações cidade-campo e sobre as sociedades que as produzem, aumentando o nosso poder de atuar sobre a realidade social.

Entretanto, essas transformações não podem ser atribuídas exclusivamente ao turismo, já que as tendências globalizantes da contemporaneidade são potencialmente 
capazes de alterar substancialmente a natureza da vida social cotidiana. Novelas e seus modismos ditando novas regras, estilos em voga, linguagem, música, padrões de beleza - tudo isso corrobora para despertar na população local novas necessidades e valores. $\mathrm{O}$ turismo, contudo, contribui para acelerar este processo em Conceição de Ibitipoca, gerando no "nativo" um paradoxo identitário entre a sua cultura de origem e uma nova cultura urbana e globalizante que se apresenta, cuja instância mediadora é atribuída ao turista, ao "estrangeiro", ao "de fora".

Ibitipoca reproduz, assim, o futuro provável de outras pequenas localidades rurais brasileiras submetidas a processos de intervenção socioespaciais semelhantes. Se devidamente planejadas, tais alterações podem ser atenuadas, com vistas à sustentabilidade do processo - desde que o planejamento seja pautado na realidade social local, com vistas a se alcançar formas mais humanizadas de turismo, no sentido de as populações afetadas construírem a sua alteridade [territorial, econômica e cultural]. Principalmente porque muitas vezes o que está em jogo é o futuro de trabalhadores rurais já calejados com as discrepâncias históricas da estrutura agrária brasileira; atores que tradicionalmente estiveram à margem dos processos políticos nacionais e, muitas vezes, foram fortemente estigmatizadas pelos grupos dominantes.

Sendo assim, nossos estudos pretendem avançar no sentido de aprofundar o tratamento dessa questão sob a perspectiva intergeracional dos processos sociais neste espaço, diagnosticando trajetórias e estratégias familiares em face das situações de mudança - a interconexão de casos aparentemente isolados de expropriação e reestruturação fundiária; a interdependência dos grupos conflitantes no espaço analisado; a continuidade e/ou ruptura na transmissão, ao longo das gerações, do patrimônio sociocultural que sustentava a dinâmica agrária de outrora. 


\section{Referências}

ABRAMOVAY, R. Funções e medidas da ruralidade no desenvolvimento contemporâneo. Rio de Janeiro: IPEA, 2000. (Texto para Discussão n ${ }^{0}$ 702).

ALBERTI, V. História oral: a experiência do CPDOC. Rio de Janeiro: Ed. FGV,1990. AOUN, Sabáh. Paraíso à vista - os jardins do éden oferecidos pelo turismo. In: RODRIGUES, A.B. (org.). Ecoturismo no Brasil: possibilidades e limites. São Paulo: Contexto, 2003. p.15-27.

BEDIM, Bruno P. O processo de intervenção social do turismo na Serra de Ibitipoca (MG): Simultâneo e desigual, dilema camponês no "Paraíso do Capital". 408 f. 2008. Dissertação (Mestrado em Geografia). Belo Horizonte: Instituto de Geociências da UFMG.

. O espaço capitalista da natureza e seu (contra) uso turístico: a dialética da visitação pública em áreas protegidas. Caderno de Turismo, Rio de Janeiro, v.7, n.3, 2007, p.75-89. Disponível em < http://www.ivt.coppe.ufrj.br/caderno/ojs/ >.

Turismo e Mudanças Socioculturais em Conceição de Ibitipoca. 2005. 99f. Monografia (Bacharelado em Turismo) - Departamento de Turismo/UFOP, Ouro Preto. BEDIM, Bruno P.; TUBALDINI, M. A. S. Turismo e populações rurais do entorno de Unidades de Conservação: dilemas socioambientais entre diferentes formas de apropriação do território. Ciência \& Tecnologia - OLAM, Rio Claro (SP), v.6, n.2, 2006, p. 356-376.

CANDIDO, A. Os parceiros do Rio Bonito: estudo sobre o caipira paulista e a transformação dos seus meios de vida. 10.ed. São Paulo: Duas Cidades; Ed. 34, 2003.

CASTRO, L. Parque Ibitipoca recebe 17 mil visitantes.Jornal Zona da Mata.[S.1.], 20 fev.1994.

CLAVAL, P. O papel da nova geografia cultural na compreensão da ação humana. In: ROSENDAHL, Z.; CORRÊA, R.L.(Orgs.). Matrizes da geografia cultural. Rio de Janeiro: EDUERJ, 2001.

COMERFORD, John. Comunidade Rural. In: MOTTA, Márcia (org.). Dicionário da Terra. Rio de Janeiro: Civilização Brasileira, 2005. p.112-120

COOPER, C. et al. Turismo, princípios e prática. 2.ed. Porto Alegre: Bookman, 2001.

DELGADO, A. M. Memória histórica sobre a cidade de Lima Duarte e seu município. Juiz de Fora: Edição do autor, 1962. 340 p.

DIÁRIO MERCANTIL. Abandono empobrece a Serra. Juiz de Fora, 12 dez. 1971. 
ELIAS, N; SCOTSON; J.L. Os estabelecidos e os outsiders: sociologia das relações de poder a partir de uma pequena comunidade. Rio de Janeiro: Jorge Zahar, 2000.

ELIAS, N. Escritos \& Ensaios: Estado, Processo, Opinião Pública. (Apresentação e organiz. de Federico Neiburg e Leopoldo Waizbort). Rio de Janeiro: Jorge Zahar, 2006. FILETTO, F. Espaço econômico e social do ecoturismo. In: VITORINO, M.R.; FONTES, M.A.L; FILETTO, F. (Orgs). Introdução ao turismo responsável. Lavras: UFLA/FAEPE, 2004. p. 31-70.

FUNDAÇÃO JOÃO PINHEIRO - FJP. Plano Diretor de Organização Territorial e Desenvolvimento do Turismo em Conceição de Ibitipoca. Belo Horizonte, 2000.

GIULIANI, G.M. Neo-ruralismo: o novo estilo dos velhos modelos. Revista Brasileira de Ciências Sociais, n.14, p.59-67, out.1990.

HALL, S. A identidade cultural na pós-modernidade. 10.ed. Rio de Janeiro: DP\&A, 2005.

KRIPPENDORF, J. Sociologia do Turismo. 3.ed. São Paulo: Aleph, 2003.

LEFEBVRE, H. Perspectivas da sociologia rural. (Tradução de C. Sarti e S. Padilha). In: MARTINS, J.S. (org.). Introdução crítica à sociologia rural. São Paulo: Hucitec, 1981. p.163-177.

. A revolução urbana. Trad. Sérgio Martins. Belo Horizonte: UFMG, 2004.

LEVI-STRAUSS, C. Raça e história. In: Levi-Strauss: Os Pensadores. Trad. Inácia Canelas. São Paulo: Abril Cultural, 1976. (Os Pensadores).

LICKORISH, L.; JENKINS, C. L. Introdução ao turismo. Rio de Janeiro: Campus, 2000 .

MARTINS, José de Souza. As coisas no lugar (da ambigüidade à dualidade na reflexão sociológica sobre a relação cidade-campo). In: MARTINS, J.S.(org.). Introdução crítica à sociologia rural. São Paulo: Hucitec, 1981. p.11-38. . A chegada do estranho. São Paulo: Hucitec, 1993.

MOREIRA, R. J. Ruralidades e globalizações: ensaiando uma interpretação. In: MOREIRA, R.J. (Org.). Identidades sociais: ruralidades no Brasil contemporâneo. Rio de Janeiro: DP\&A, 2005. p.15-40.

NEIBURG, F.; WAIZBORT, L. Apresentação. In: ELIAS, N. Escritos \& Ensaios: Estado, Processo, Opinião Pública. Rio de Janeiro: Jorge Zahar, 2006. p.7-20.

OLIVEIRA, A.U. Geografia Agrária: perspectivas no início do século XXI. In: OLIVEIRA, A.U.; MARQUES, M.I.M. O campo no século XXI: território de vida, de 
luta e de construção da justiça social. São Paulo: Casa Amarela; Paz e Terra, 2004. p.29-70.

QUEIROZ, M.I.P. Do rural e do urbano no Brasil. In: SZMRECSÁNYI, T.; QUEDA, O. (orgs.). Vida rural e mudança social. 3.ed. São Paulo: Nacional, 1979. p.160-176.

RESENDE, T. C. C. Dinâmica do contato dialetal: estudo sociolingüistico em Conceição de Ibitipoca. Tese de Doutoramento em Lingüística (Resultados Preliminares) - UFRJ, 2005.

REVISTA MANCHETE. Ibitipoca: com o boom do turismo, o arraial se adapta a uma nova vida. Rio de Janeiro, 22 jul. 1995.

RODRIGUES, C. G. O turismo e a reconstrução do espaço rural: o causo do arraial de Conceição do Ibitipoca(MG). 2001.Dissertação (Mestrado em Desenvolvimento, Agricultura e Sociedade) - UFRRJ.

RUSHMANN, D. Turismo e planejamento sustentável. São Paulo: Papirus, 2001.

SILVA, J.G. O novo rural brasileiro. Revista Nova Economia, Belo Horizonte, v.7, n.1, p.43-81, maio 1997. Disponível em: <eco.unicamp.br/projetos/rurbano7.html>.

SILVA, M.A. M. A luta pela terra: experiência e memória. São Paulo: UNESP, 2004.

SIMMEL, G. "O estrangeiro". Tradução de Carlos Pavanelli et al. In: MORAES FILHO, E. (org). Georg Simmel: sociologia. São Paulo: Ática, 1983. p.182-88.

THIOLlENT, M. Metodologia da Pesquisa-ação. 12.ed. São Paulo: Cortez, 2003.

TRIBUNA DE LIMA DUARTE. Serra de Ibitipoca, um paraíso perdido. Lima Duarte, 22 mar. a 05 abr. 1987.

VIEIRA, M. E. G. Ibitipoca: um caldeirão efervescente. Juiz de Fora: UFJF, 1988. (Trabalho de Bacharelado, Departamento de Ciências Sociais/ UFJF).

WANDERLEY, M.N.B. A emergência de uma nova ruralidade nas sociedades modernas avançadas - o "rural" como espaço singular e ator coletivo. Estudos Sociedade e Agricultura, Rio de Janeiro, v.15, p.87-145, out. 2000.

YÁZIGI, E. A alma do lugar. São Paulo: Contexto, 2001. (Coleção Turismo Contexto) 